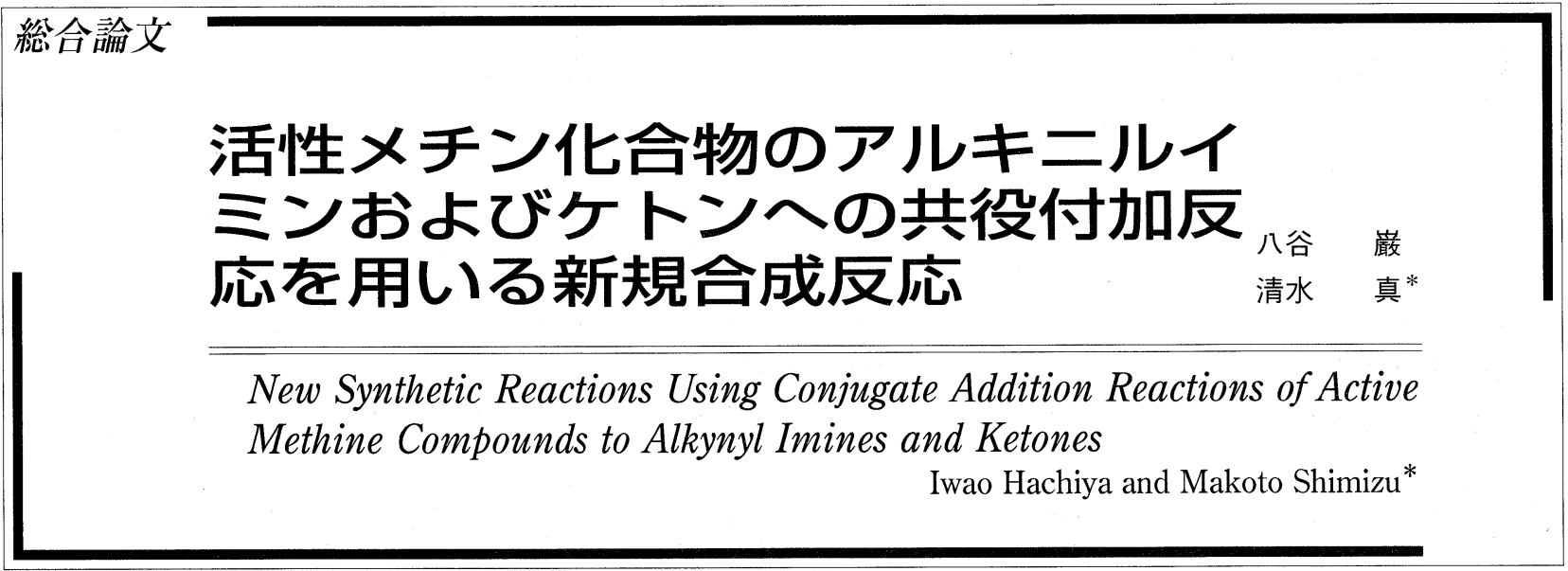

The development of the synthetic methods of functionalized 2-pyridones is important as a result of the large number of biologically active compounds containing a 2-pyridone structure and as dienes in Diels-Alder cycloadditions. Many methods for the synthesis of 2 -pyridones have been reported. We have found a 5 -alkoxycarbonyl-2-pyridone synthesis via the nucleophilic addition of malonic esters to alkynyl imines in good yields. It is also found that the reaction of $\beta$-keto esters with alkynyl imines give 5-acetyl-2-pyridones in good yields. On the other hand, the reactions of dialkynyl imines instead of alkynyl imines with active methine compounds give $3,4,5$, 6-tetrasubstituted-2-pyridones. We have found that the reactions of alkynylpyridines, pyrimidine, or thiazoles with malonic esters give bicyclo-2-pyridones in moderate to good yields. The conjugate addition reactions of various cyclic $\beta$-keto esters with alkynyl imines proceed and then the intramolecular cyclization reactions take place. The subsequent cleavage reactions give two-atom enlarged carbocyclic products in good yields. We have also found the reactions of malonic esters or $\beta$-keto esters with alkynyl ketones give 5 - alkoxycarbonyl-2-pyrones or 5-acetyl-2-pyrones in good yields.

Key words: 2-pyridone, alkynyl imine, active methine compound, alkynylpyridine, alkynylthiazole, bicyclo-2-pyridone, conjugate addition, ring-expansion reaction, alkynyl ketone, 2-pyrone

はじめに

酸素原子，窒素原子，硫黄原子やリン原子などへテロ 原子を含むへテロ環化合物は，核酸，ビ夕ミン，抗生物 質や糖などの天然有機化合物や, 合成医薬品, 農薬, 染 料や高分子などの様々な物質の構造に含まれている。ま た，合成中間体としても広く利用されており，へテロ環 化合物の新規合成法の開発は，いまなお活発に行われて いる。その中でも, $\beta$-ラク夕ム系抗生物質をはじめと する含窒素化合物の新規合成反応の開発は，最もよく研 究されている分野である。窒素原子を有する化合物合成 においてよく用いられる化合物として，アルデヒドと一 級アミンとから脱水反応によって容易に合成できるイミ ンがある。本研究ではイミンの中でも三重結合を有する アルキニルイミンに，2 位に置換基を持つマロン酸ジエ ステルを活性メチン化合物として作用させたところ，5 位にアルコキシカルボニル基を有する2-ピリドンが得 られることを見出した。そこで従来にはないこの 2-ピ

\section{* 三重大学工学部分子素材工学科}

* Department of Chemistry for Materials, Mie University pepartment of Chemis
リドン生成の反応機構に着目し, 種々の活性メチン化合 物へと適用した。さらにビシクロー2-ピリドンを合成す るために，イミン等価体としてアルキニルピリジン，ピ リミジンやチアゾールに応用した。また，中員環化合物 を得るために活性メチン化合物として環状 $\beta$-ケトエス テルおよび $\alpha$-シアノケトンを用いた。さらに，アルキ ニルケトンを用いる2-ピロン合成へと応用した。本総 合論文では以下の反応を紹介する。

1）活性メチン化合物のアルキニルイミンへの共役付加 反応を用いる多置換 2-ピリドンの合成

2）活性メチン化合物のアルキニルイミン等価体への共 役付加反応を用いる多置換ビシクロー2-ピリドンの合 成

3）電子求引基を有する環状ケトンのアルキニルイミン への共役付加を経る環拡大反応による中員環の合成

4）活性メチン化合物のアルキニルケトンヘの共役付加 反応を用いる多置換 2-ピロンの合成

1. 活性メチン化合物のアルキニルイミンへの共役付 加反応を用いる多置換 2-ピリドンの合成

含窒素化合物を合成する方法の 1 つとして，ケテンシ リルアセタールとイミンとのイミノアルドール反応があ 
り， $\beta$-ラクタム環をはじめとする生理活性化合物合成 における有用な合成中間体である $\beta$-アミノエステルを 合成する重要な手法である。私どもの研究室では, イミ ンとして二重結合を有するアルケニルイミン 1 にケテン シリルアセタール 2 を四塩化チタンの存在下作用させる と, 2 当量のケテンシリルアセタールがアルケニルイミ ンの $\beta$-炭素とイミノ炭素に，それぞれ付加した $1,4-1$, 2 -二重求核付加体 3 が良好な収率で得られることを見出 している。この反応では, 求核剤としてケテンシリルア セタールとアリルスズ化合物を反応させた場合, ケテン シリルアセタールが $\beta$-炭素に, またアリルスズ化合物 4 がイミノ炭素に付加した 1, 4-1,2-二重求核付加体 5 が得られることも明らかにしている1)。この反応では, 一番目の求核剂であるケテンシリルアセタール $(N u 1)$ が アルケニルイミン 6 に1,4-付加して生成したメタロエ ナミン 7 が, 反応系内の水または金属種によってイミン 8 に異性化した後，ケテンシリルアセタールまたはアリ ルスズ化合物などの 2 番目の求核剤 (Nu2) が 1,2-付加 することによって 1,4-1,2-二重求核付加体 9 が生成し ている(スキーム 1)。
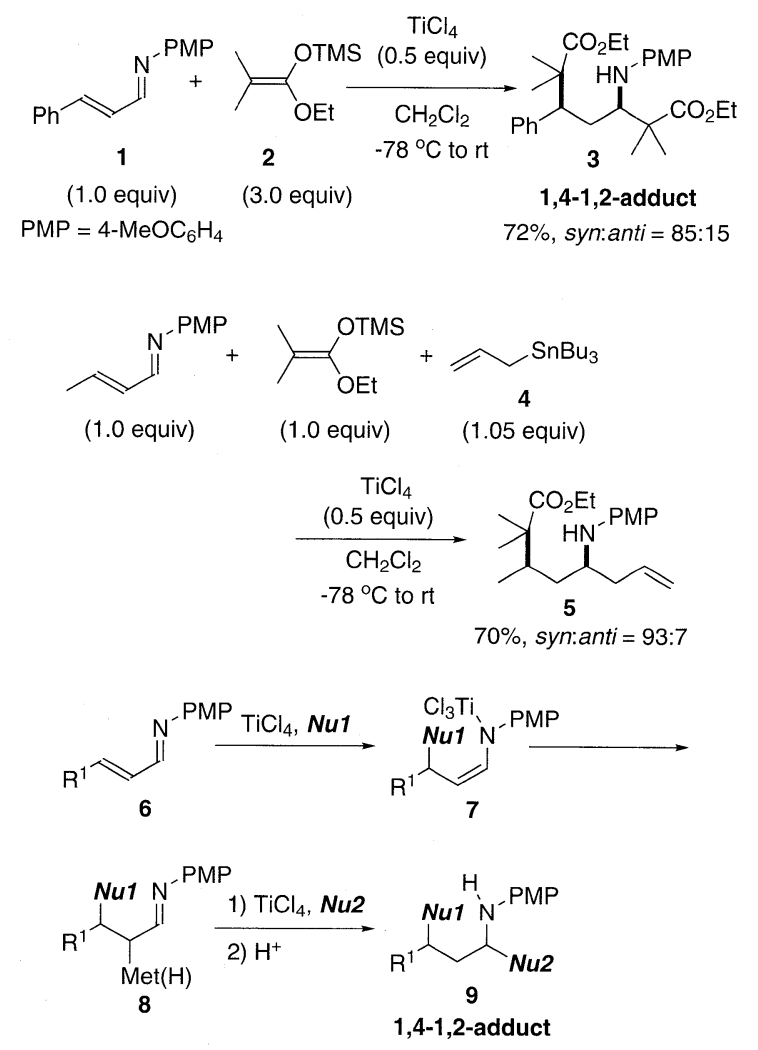

Scheme 1

そこで次に，この 1,4-1,2-二重求核付加反応を三重 結合を有するアルキニルイミンへ適用する検討をした。 すなわち, 一番目の求核凨であるケテンシリルアセター ル(Nu1)が，アルキニルイミン 10 に1,4-付加して生成 したメタロアレナミン 11 が反応系内の水または金属種
によってイミン 12 に異性化した後，2番目の求核㓮 (Nu2)が 1,2-付加することによって，様々な官能基へ 変換可能な二重結合を持つ 1,4-1,2-二重求核付加体 13 が得られるものと考えた(スキーム 2)。まず，フェニル プロピナールと4-メトキシフェニルアミンから調製し たアルキニルイミン 14 と, イソ酪酸エチルエステル由 来のケテンシリルアセタール 2 との反応を行った。その 結果，1，4-1,2-二重求核付加体 15 は全く得られず, 1,2-付加体 16 のみが定量的に得られた(スキーム 2)。
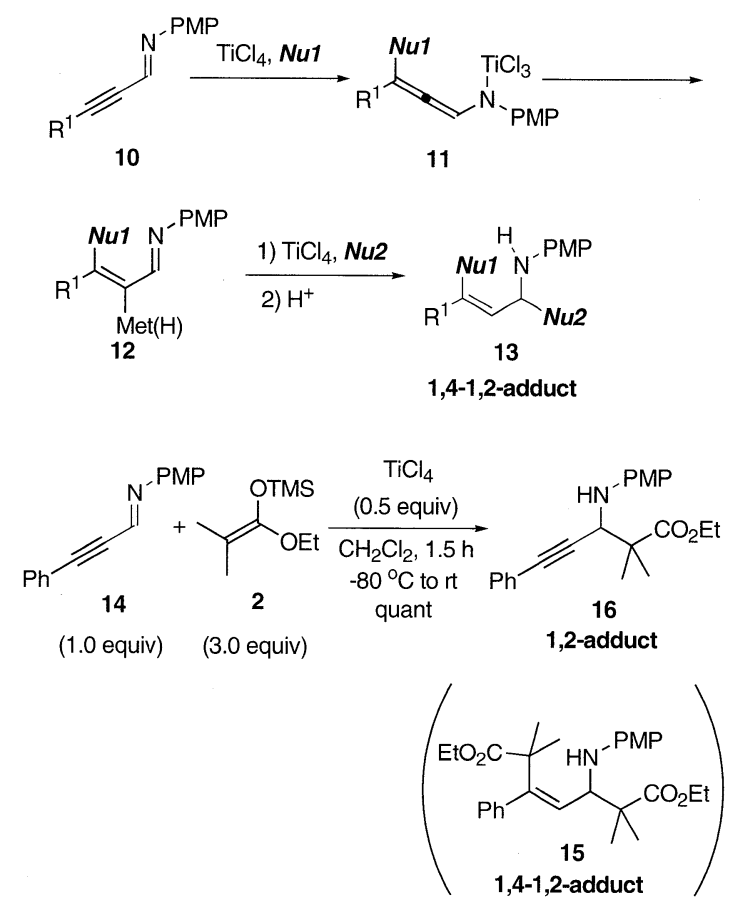

Scheme 2

そこで，共役付加反応における良い求核㓣として知ら れている活性メチレン化合物のジメチルマロナート 17 を用い反応を行った。その結果, 望みの1,4-1,2-二重 求核付加体は得られず，3 位にメトキシカルボニル基を 有する 2 -ピリドン 18 が得られた(スキーム 3 )。マロン 酸ジエステルは望みどおり $\beta$-炭素に共役付加したが, 活性プロトンをもう1つ有しているため, 中間体のメ夕 ロアレナミンからメタロエナミンに異性化した後, 分子 内環化反応が進行した結果，2-ピリドン 18 が生成した と考えられる。

そこで，このメタロアレナミンからメタロエナミンへ の異性化を防ぐために，2 位に置換基を有するマロン酸 ジエステルとしてジ、チル,チルマロナート 19 を用い 反応を行った。その結果，5位にメトキシカルボニル基 を持つ 2 -ピリドン 20 が得られることを見出した(ス キーム 4)。これは, ジエチルメチルマロナートのナト リウム塩 21 が共役付加反応することによって生成した メタロアレナミン 22 が, 同一分子内のエトキシカルボ ニル基に求核付加することによってシクロブテノキシド 

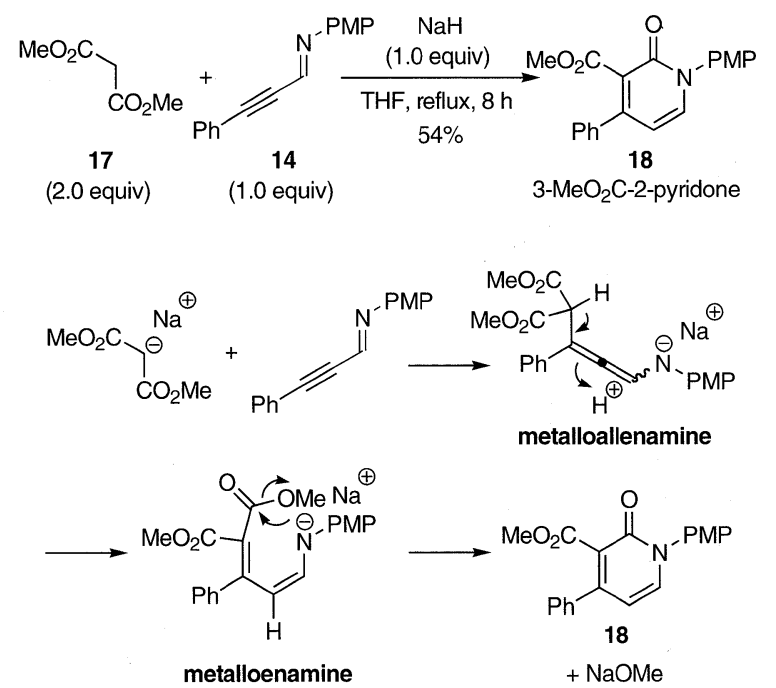

Scheme 3
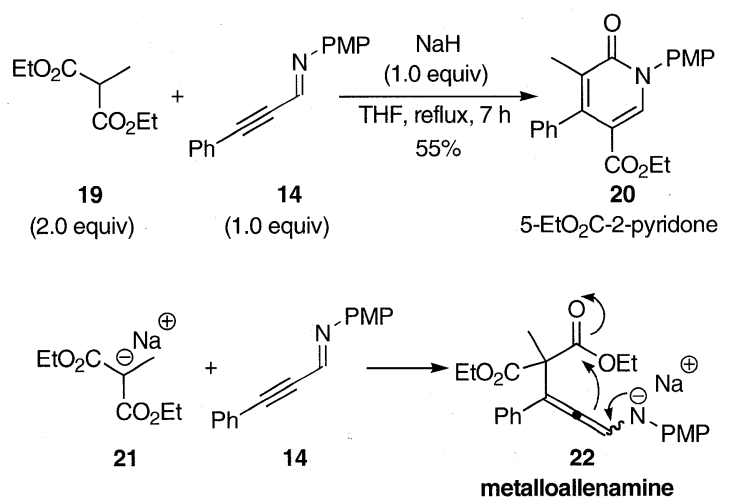

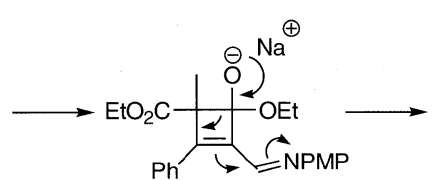

23

cyclobutenoxide

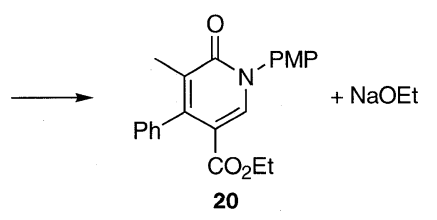

Scheme 4

23 を生成し，その後，シクロブテノキシド 23 の開環反 応によってメタロエナミン 24 が生成し, 最後に分子内 求核付加反応によって，5位にエトキシカルボニル基を 持つ2-ピリドン 20 が生成したものと考えられる(ス キーム 4$)^{2)}$ 。

多官能基を有する 2-ピリドン合成反応の開発は，2ピリドン骨格構造を持つ生理活性化合物が多く存在する ことから ${ }^{3)}$ ，これまでにも数多くの合成法が報告されて いる ${ }^{4)}$ 。最近では，遷移金属を用いた多置換 2-ピリドン 合成法が報告されている $(\text { スキーム 5 })^{5)}$ 。

また，2-ピリドンは Diels-Alder 反応のジエンとして 用いられている6)。しかしながら，5位にアルコキシカ
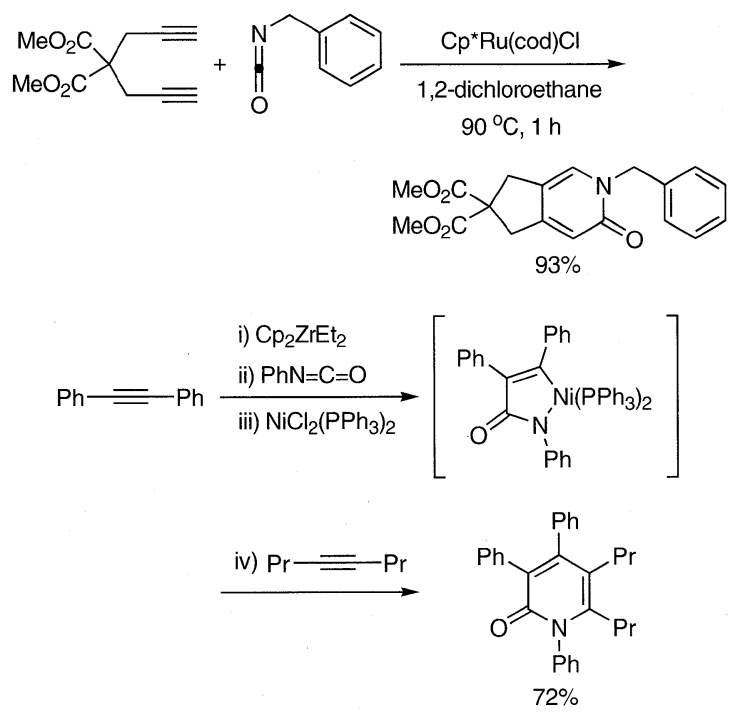

Scheme 5

ルボニル基を持ち，かつ 3 位，4位の置換基を同時に制 御した報告例はなかった。新たに見出したこの2-ピリ ドン合成反応では，種々のアルキニルイミンおよびマロ ン酸ジエステルを用いることができる(表 1)。

ジエチルメチルマロナートにかえジメチルメチルマロ ナート $25\left(\mathrm{R}^{1}=\mathrm{Me}\right)$ を用いると収率は向上し，収率 $91 \%$ で対応する 2 -ピリドン 27 を得ることができる。ア ルキニルイミンの置換基として，フェニル基のようなア リール基だけでなく，ブチル基や TBS オキシプロピル 基のような脂肪族や二重結合を持つシクロヘキセニル基 を有するアルキニルイミン 26 も用いることができ，良 好な収率で対応する 2-ピリドン 27 を与える。また，マ ロン酸ジエステルの置換基としてアリル基を有するジメ チルアリルマロナートを用いると，3位に官能基変換可 能なアリル基を有する 2 -ピリドン 27 を得ることができ る。この2-ピリドン合成反応では副生生物として，5位 にアルコキシカルボニル基を有さない 2 -ピリドンが生 成してくる(表 1，エントリー4の場合収率 11\%)。そこ で，この副生生物が生成してくる反応機構を明らかにす るために，ジメチルメチルマロナートのかわりにジベン ジルメチルマロナート 28 を用い反応を行った結果, 5

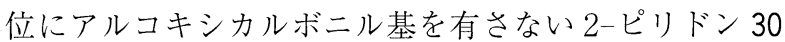
と炭酸ジベンジル 31 がほぼ同じ収率で得られたことか ら，スキーム 6 に示す反応機構で生成したものと考えら れる。すなわち，スキーム 4 と同様に，生成したメ夕口 アレナミン 32 のプロトン化によりアルケニルイミン 33 が生成し，その後，そのアルケニルイミンのベンジルオ キシカルボニル基に，望みの 5 位にベンジルオキシカル ボニル基を有する 2 -ピリドン 29 が生成する際に副生し たナトリウムベンジルオキシドが求核攻撃し，炭酸ジベ ンジル 31 の脱離を伴いながら，環化することによって， 5 位にアルコキシカルボニル基を有さない 2 -ピリドン 
Table 1 2-Pyridone synthesis via nucleophilic addition of malonic esters to alkynyl imines.

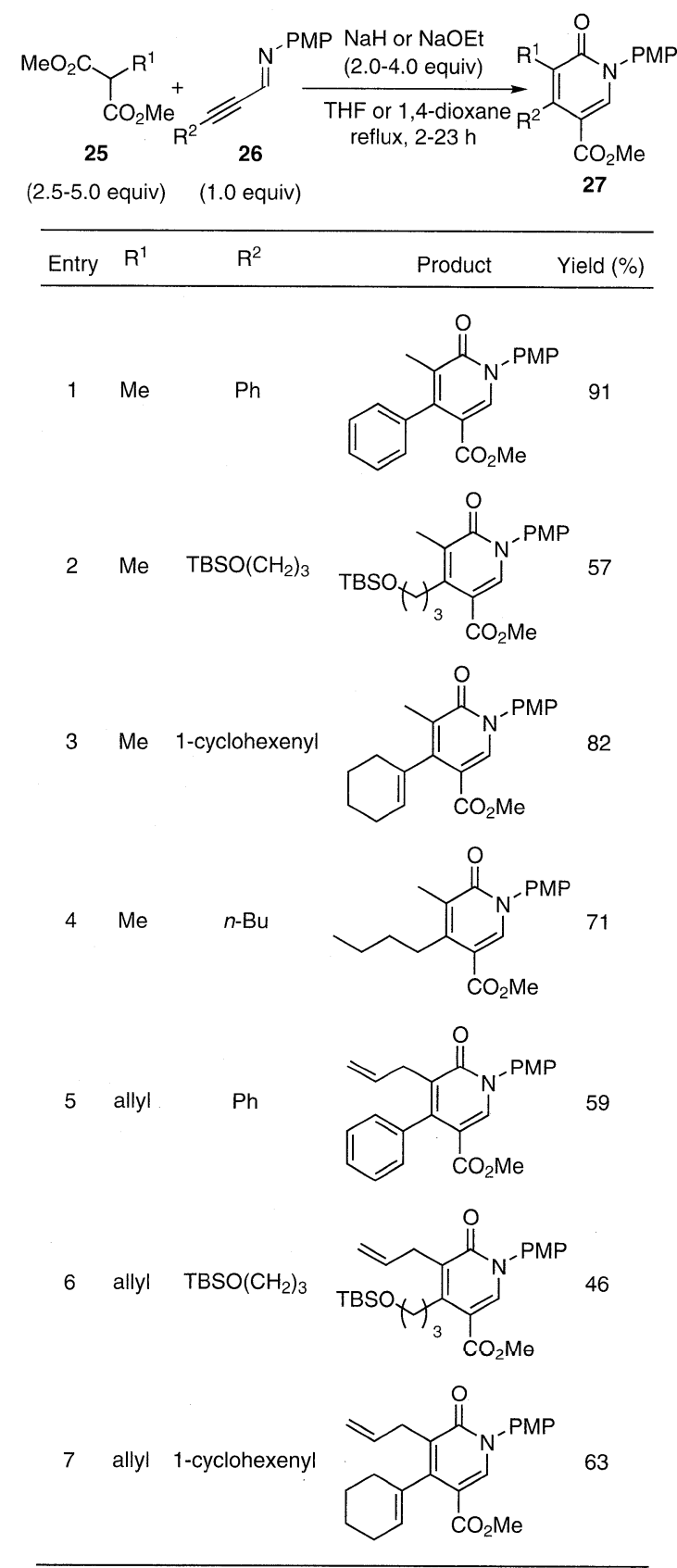

30 が生成したものと考えられる(スキーム 6)。

この反応では，2 位に置換基を有するマロン酸ジエス テル以外の活性メチン化合物として，2 位に置換基を有 する $\beta$-ケトエステル 34 を用いることもでき， 5 位にア セチル基を有する 2 -ピリドン 35 を得ることができる ${ }^{7)}$ 。 マロン酸ジエステルに比べ求核性が弱いため，収率は低 下したが，対応する 5 位にアセチル基を有する 2 -ピリ ドン 35 を中程度の収率で得ることできる(表 2)。

これは， $\beta$-ケトエステルのナトリウム塩 36 がアルキ ニルイミンに共役付加反応することによって生成したメ タロアレナミン 37 が，同一分子内のアセチル基に選択 的に求核付加することによってシクロブテノキシド 38

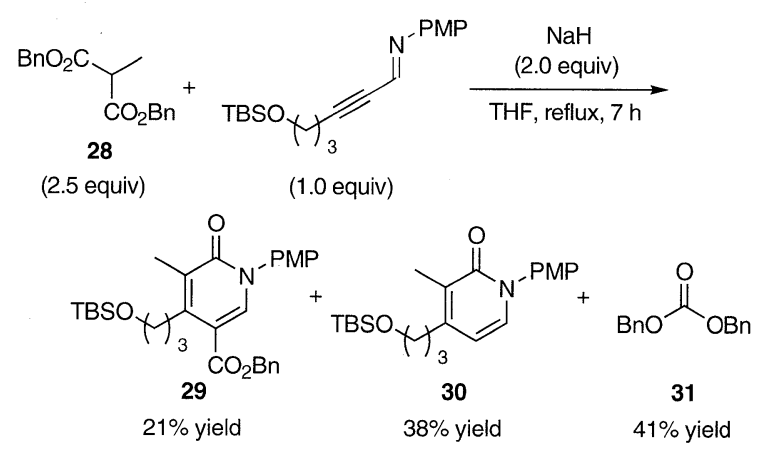

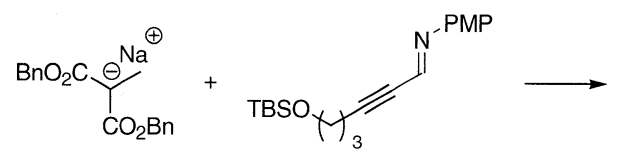<smiles>CC(C)O[13C](=O)[O-]</smiles>
33

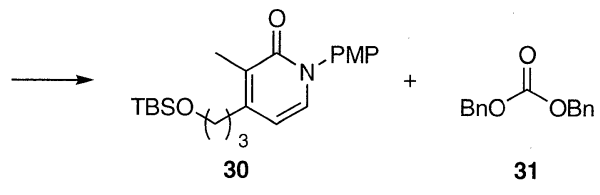

Scheme 6

を生成し, その後, シクロブテノキシド 38 の開環反応 によってメタロエナミン 39 が生成し, 最後に分子内ア ミド化反応によって 5 位にアセチル基を持つ 2-ピリド ン 35 が生成したものと考えられる(スキーム 7)。

アルキニルイミンに，2 位に置換基を有するマロン酸 ジエステルや $\beta$-ケトエステルのような活性メチン化合 物を反応させることにより，3，4，5-三置換-2-ピリドン が得られることを明らかにした。方，2ーピリドン骨格 を持つ生理活性化合物には 3 位, 4 位, 5 位, 6 位に置 換基を有する 2 -ピリドンも多数ある。そこで次に，3,4, 5,6-四置換-2-ピリドンを得るために，アルキニルイミ ンにかえアルキニルケチミンへの適用を試みた。アルキ ルケチミンとしてジアルキニルイミンについて検討し た。ジアルキニルイミンを用いると，6位に官能基変換 可能なアルキニル基を有する2-ピリドンを得ることが できる ${ }^{8)}$ 。同一の置換基を持つジアルキニルイミン 40

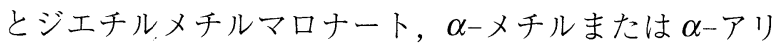
ルアセト酢酸エチル 41 のナトリウム塩との反応では, 中程度から良好な収率で 3, 4, 5, 6-四置換-2-ピリドン 42 を得ることができる(表 3，エントリー1-4)。ジアルキ ニルイミンの置換基に関して異なるイミンの場合には, 立体的に空いている sp 炭素で反応は進行し，対応する 3, 4, 5, 6-四置換-2-ピリドン 42 を与える(表 3, エント リ) $5-10)$ 。 
Table 2 2-Pyridone synthesis via nucleophilic addition of $\beta$-keto esters to alkynyl imines.

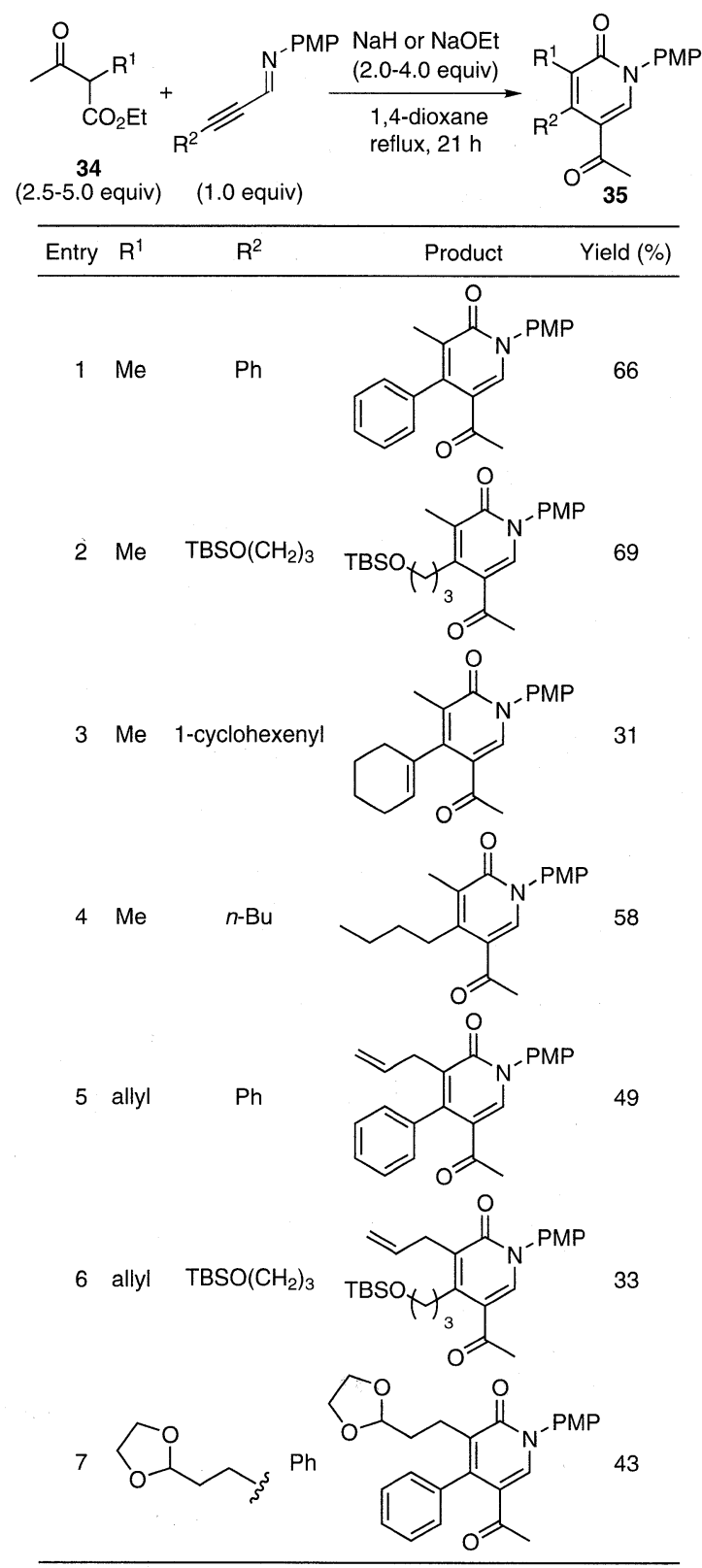

2. 活性メチン化合物のアルキニルイミン等価体への 共役付加反応を用いる多置換ビシクロ-2-ピリド ンの合成

新たに見出した2-ピリドン合成反応を環内に $\mathrm{C}=\mathrm{N}$ 結合を含むイミンに適用することができれば，ビシクロー 2-ピリドン 43 を合成できるのではないかと考え，アル キニルピリジン，ピリミジン，およびチアゾールをアル キニルイミン等価体 44 として用い検討した（スキーム 8) ${ }^{9)}$ 。

まず，アルキニルピリジン 45 について検討した。そ の結果，アルキニルイミンやジアルキニルイミンに比べ 反応性が低いため, 多くの反応例において 1,4-ジオキ サン中，加熱還流下では反応が若干しか進行せず，未反

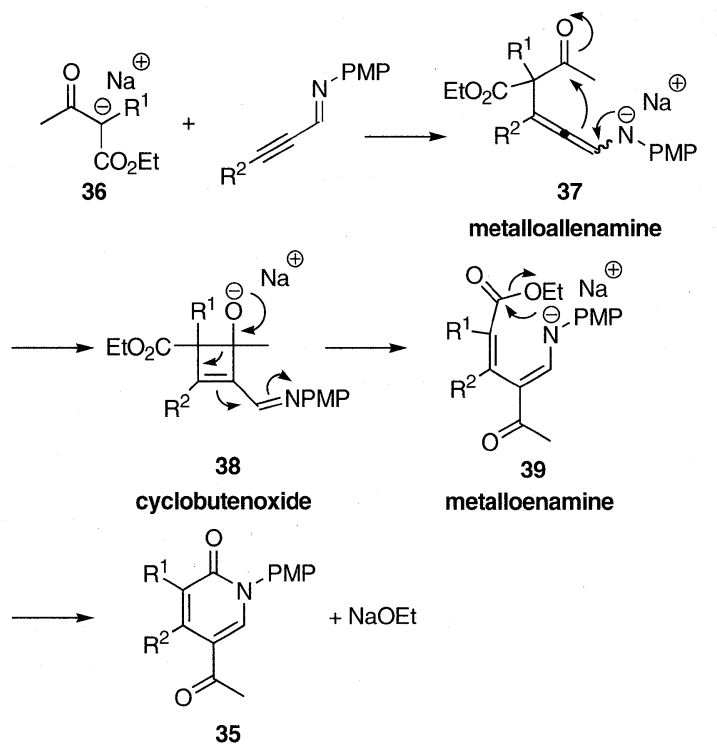

Scheme 7

Table 3 2-Pyridone synthesis via nucleophilic addition of active methine compounds to dialkynyl imines.

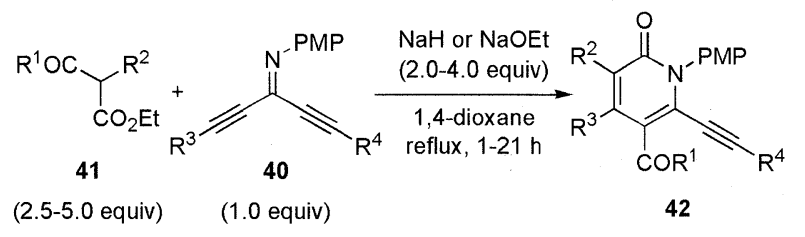

\begin{tabular}{|c|c|c|c|c|c|}
\hline Entry & $\mathrm{R}^{1}$ & $\mathrm{R}^{2}$ & $\mathrm{R}^{3}$ & $\mathrm{R}^{4}$ & Yield (\%) \\
\hline 1 & OEt & $\mathrm{Me}$ & $\mathrm{Ph}$ & $\mathrm{Ph}$ & 66 \\
\hline 2 & OEt & $\mathrm{Me}$ & $n$-Bu & $n-\mathrm{Bu}$ & 44 \\
\hline 3 & $\mathrm{Me}$ & $\mathrm{Me}$ & $\mathrm{Ph}$ & $\mathrm{Ph}$ & 52 \\
\hline 4 & $\mathrm{Me}$ & $\mathrm{Me}$ & $n$-Bu & $n$-Bu & 56 \\
\hline 5 & OEt & $\mathrm{Me}$ & $\mathrm{Ph}$ & TBS & 71 \\
\hline 6 & OEt & allyl & $n-\mathrm{Bu}$ & TBS & $55^{\mathrm{a}}$ \\
\hline 7 & $\mathrm{Me}$ & $\mathrm{Me}$ & $\mathrm{Ph}$ & TBS & 40 \\
\hline 8 & $\mathrm{Me}$ & $\mathrm{Me}$ & $n$-Bu & TBS & 51 \\
\hline 9 & $\mathrm{Me}$ & allyl & $n$-Bu & TBS & 42 \\
\hline 10 & OEt & & $H$ & TBS & $51^{b}$ \\
\hline
\end{tabular}

2-Pyridone $\left(R^{2}=(E)\right.$-1-propenyl) possessing a double bond that isomerized internally was obtained. ${ }^{b}$ The imine was added dropwise using a syringe pump to the solution of the sodium salt of $\beta$-keto ester in 1,4-dioxane under reflux.<smiles>[R]C([18OH])C([R])C(=O)O</smiles>

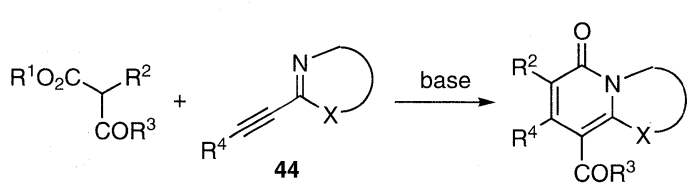

43

Scheme 8 
応のアルキニルピリジンを回収した。そこで, 種々反応 条件を検討した結果，ジエチレングリコールジメチル エーテル中, $150{ }^{\circ} \mathrm{C}$ で反応は進行し, 用いた $\alpha$-置換マ ロン酸ジエステル 46 やアルキニルピリジン 45 によって 収率に差はあったが，最高 77\%で対応寸るビシクロ-2ピリドン 47 を得ることができた(表 4) ${ }^{10,11) 。 ~}$

Table 4 Bicyclo-2-pyridone synthesis via nucleophilic addition of malonic esters to alkynylpyridines.

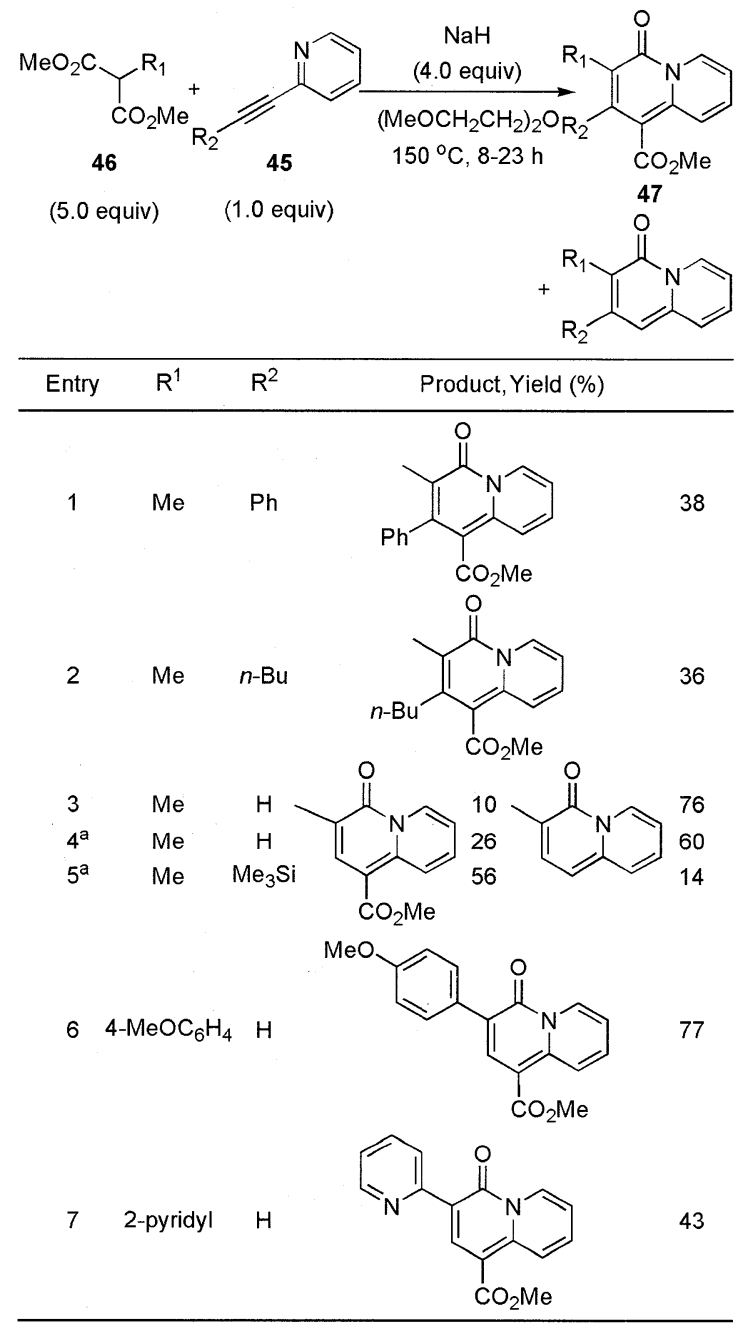

a These reactions were carried out using $\mathrm{NaH}$ (2.0 equiv) and dimethyl methylmalonate (2.5 equiv) in 1,4-dioxane under reflux.

次にアルキニルピリミジン 48 について検討した。そ の結果，反応は進行したが，対応するビシクロ-2-ピリ ドン 49 の収率は中程度であった $(\text { スキーム } 9)^{12)}$ 。

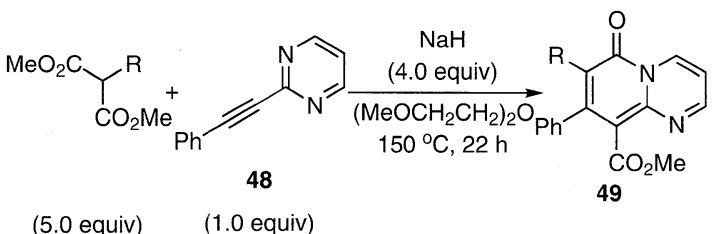

(5.0 equiv) (1.0 equiv)

$\mathrm{R}=\mathrm{Me}: 48 \%$ $\mathrm{R}=$ allyl: $30 \%$

Scheme 9

一方，アルキニルイミン等価体としてアルキニルチア ゾール 50 を用いると, アルキニルピリジン 45 やピリミ
Table 5 Bicyclo-2-pyridone synthesis via nucleophilic addition of malonic esters to alkynylthiazoles.

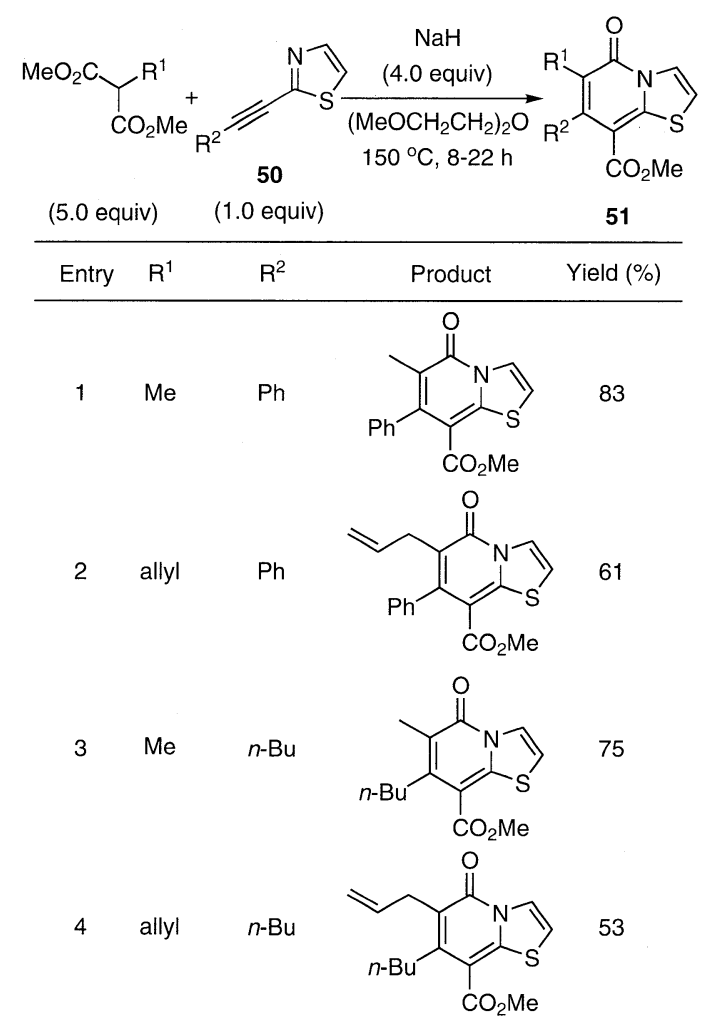

ジン 48 に比べ反応は円滑に進行し, 良好な收率で対応す るビシクロ-2-ピリドン 51 を得ることができる(表 5) ${ }^{13)} 。$

アルキニルイミン等価体を用いたビシクロー2-ピリド ン合成反応の反応機構をスキーム 10 に示す。
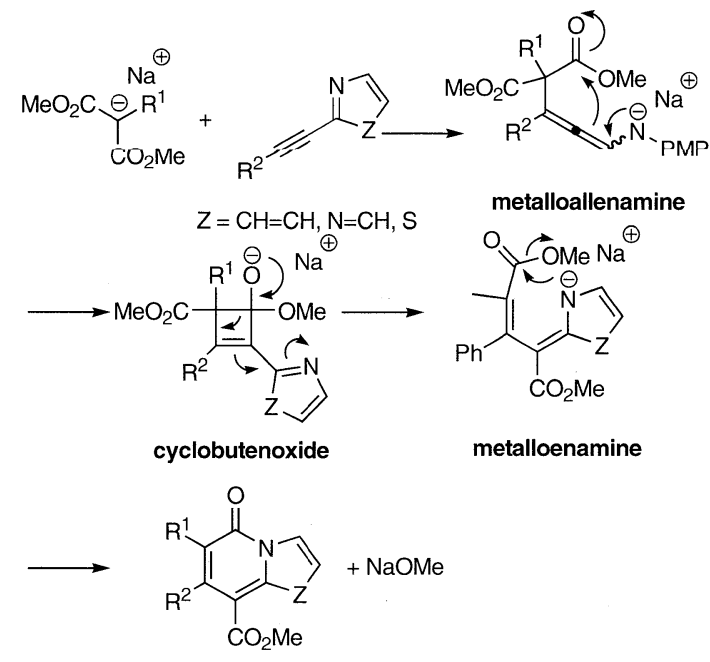

Scheme 10

アルキニルイミンを用いた2-ピリドン合成反応の機 構と同様に, シクロブテノキシドを経て進行していると 考えられる。

スキーム 11 に示す (一)-A58365A および(一)A58365Bは，降血圧作用を示す2-ピリドン骨格を有す る化合物である ${ }^{14)}$ 。現在, $\beta$-ケトエステル 52 と L-メチ 
オニンから調製したキラルなアルケニルーアルキニルイ

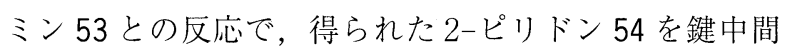
体に用いる(一)-A58365Aの全合成を検討中である(ス キーム 11) ${ }^{15)}$ 。

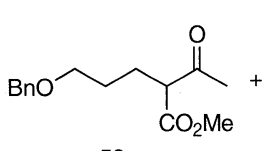

52

(2.5 equiv)

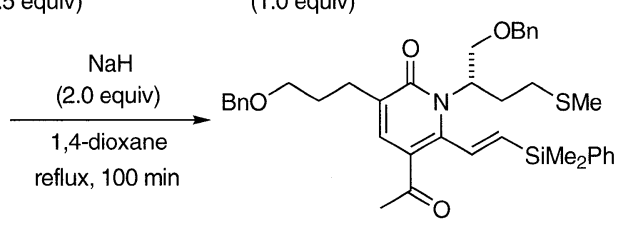

54
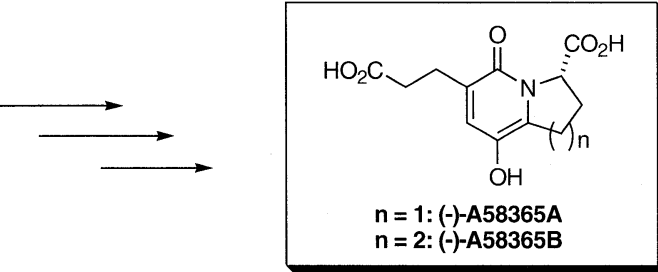

Scheme 11

3. 電子求引基を有する環状ケトンのアルキニルイミ ンへの共役付加を経る環拡大反応による中員環の

合成

鎖状のマロン酸ジエステルや $\beta$-ケトエステルを活性 メチン化合物として, アルキニルイミン, ジアルキニル イミン，およびアルキニルピリジンをはじめとするアル キニルイミン等価体に反応させることにより, 対応する 2ーピリドンを得ることができた。これらの反応を，活性 メチン化合物として環状ケトン誘導体を用い反応を行う と, 2 炭素環拡大反応が進行し, 対応するシクロアルケ ノンを得ることができる ${ }^{16)}$ 。すなわち，環状活性メチン 化合物のナトリウム塩 55 が共役付加反応することに よって生成したメタロアレナミン 56 が, 分子内カルボ ニル基に求核付加することによってシクロブテノキシド 57 を生成し, その後, 57 の開環反応によって 2 炭素環 拡大生成物のメタロエナミン 58 を経てシクロアルケノ ン 59 が $\mathrm{N}$ 上のプロトンとカルボニル酸素間の水素結合 の結果，生成する(スキーム 12)。

アルキニルイミンと環状活性メチン化合物として環状 $\beta$-ケトエステルのエチル 2-オキソシクロペンタン，へ キサン，ヘプタン，およびオクタンカルボキシラート 60 のナトリウム塩を用い反応を行うと，環拡大反応は 円滑に進行し，対応する 2 炭素環拡大生成物であるシク ロアルケノン 61 を得ることができる。アルキニルイミ ンの置換基として，フェニル基のような芳香族だけでな く，ブチル基や TBS オキシプロピル基を含む脂肪族の

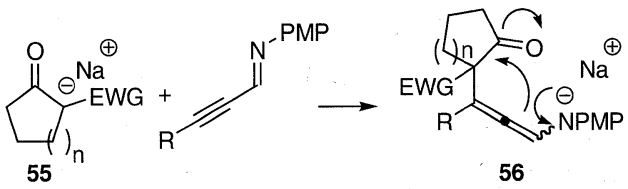

$n=1,2,3,4$

metalloallenamine

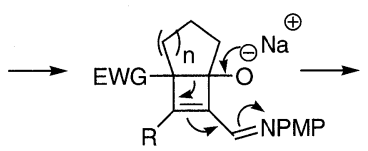

57

cyclobutenoxide.

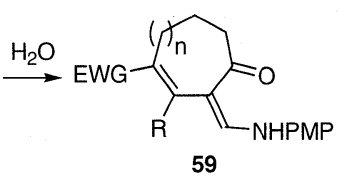

Scheme 12

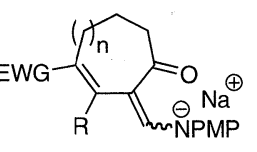

58
イミンでも収率よく環拡大生成物を得ることができる。 この反応では一般に合成の難しい中員環を構築するだけ でなく, カルボニル基，アルコキシカルボニル基および エナミンを有するシクロアルケノン誘導体を得ることが できるため, 中員環を有する生理活性化合物の全合成に おける中間体合成法の 1 つになると考えられる(表6)。

Table 6 Ring expansion reaction via conjugate addition of $\beta$-keto esters to alkynyl imines.
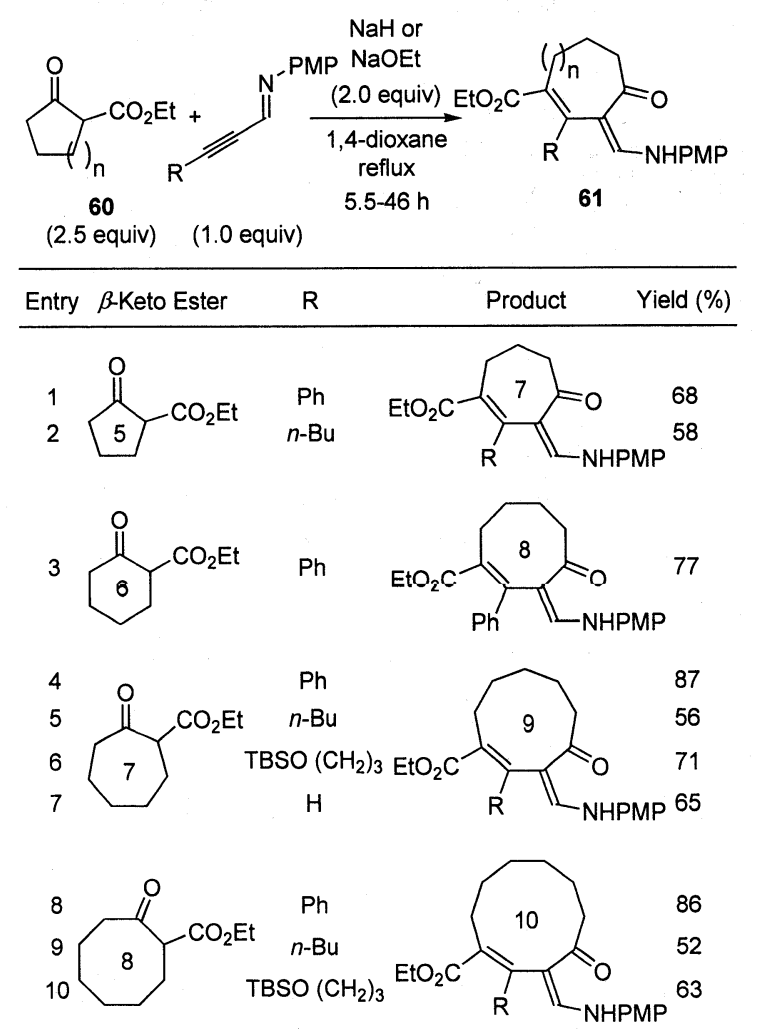

次に，さらに大きな環への適用を検討した。エチル 2-オキソシクロドデカンカルボキシラート 62 のナトリ ウム塩とブチル基を有するアルキニルイミン 63 との反 応を行ったところ, 環拡大反応が進行した後, 閉環反応 
が進行し，ビシクロ-2-ピリドン 64 が収率 $53 \%$ で得ら れた。すなわち，スキーム12 と同様に環拡大反応が進 行した後, 環をつなぐ炭素数が増え環のひずみエネル ギーが小さくなったため, 環内二重結合が異性化し，メ 夕ロエナミン部位がアルコキシカルボニル基に求核攻撃 した結果，生成したと考えられる(スキーム13)。
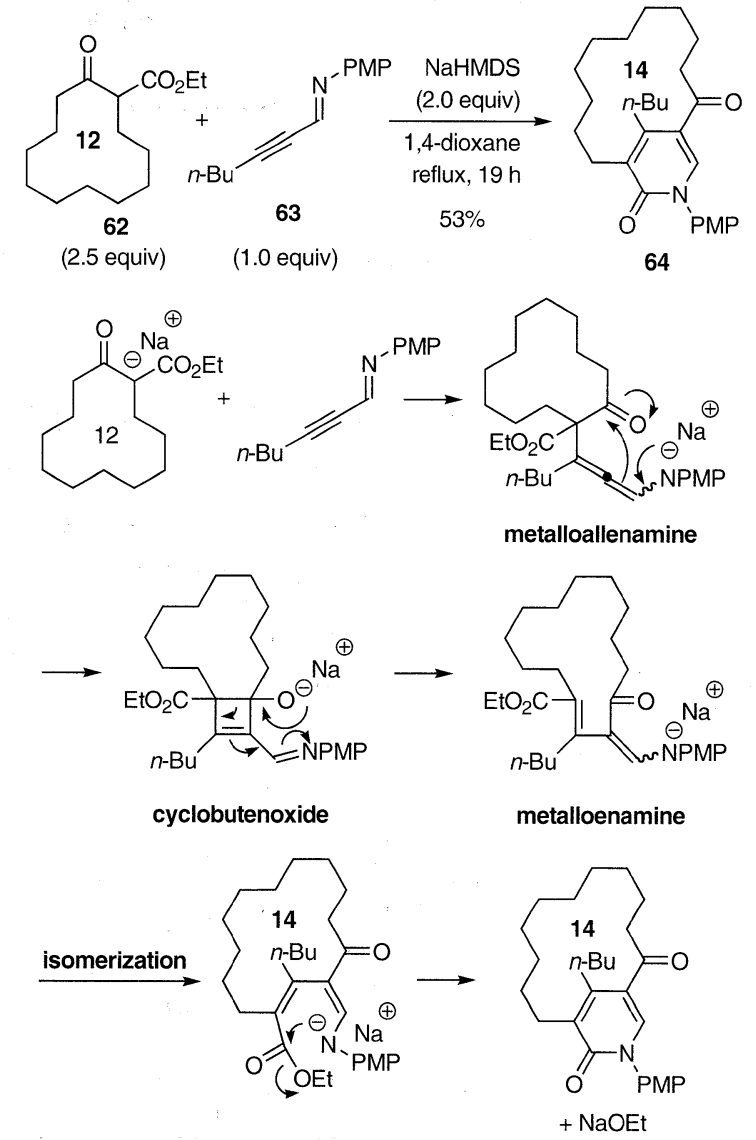

Scheme 13

環状ケトンの電子求引基としてシアノ基を有するシア ノケトン 65 を用いると, 中程度から良好な収率で環拡 大生成物であるシアノアルケノン 66 を得ることができ る(表 7)。

スキーム 14 に示す $(+)$-asteriscanolide は, シクロオ クタン環を含むセスキテルペンラクトンの一種で， 8-5-5 員環を有する三環性化合物である ${ }^{17)}$ 。現在, 環状 $\beta$-ケ トエステル 67 とアルキニルイミン 68 との反応で得られ た2-ピリドン 69 を鍵中間体に用いる $(+)$-asteriscanolide の全合成に検討中である(スキーム 14)。

\section{4. 活性メチン化合物のアルキニルケトンへの共役付 加反応を用いる多置換 2-ピロンの合成}

これまで活性メチン化合物のアルキニルイミンへの共 役付加反応を経る 2 -ピリドン合成反応，抒上び環拡大 反応による中員環合成を述べた。いずれの反応も共役付 加反応によって生成したメタロアレナミンの分子内求核
Table 7 Ring expansion reaction via conjugate addition of cyclic cyanoketones to alkynyl imines.

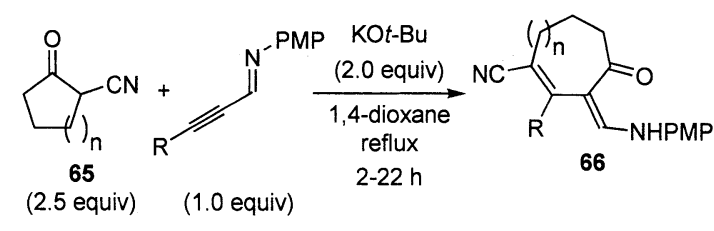

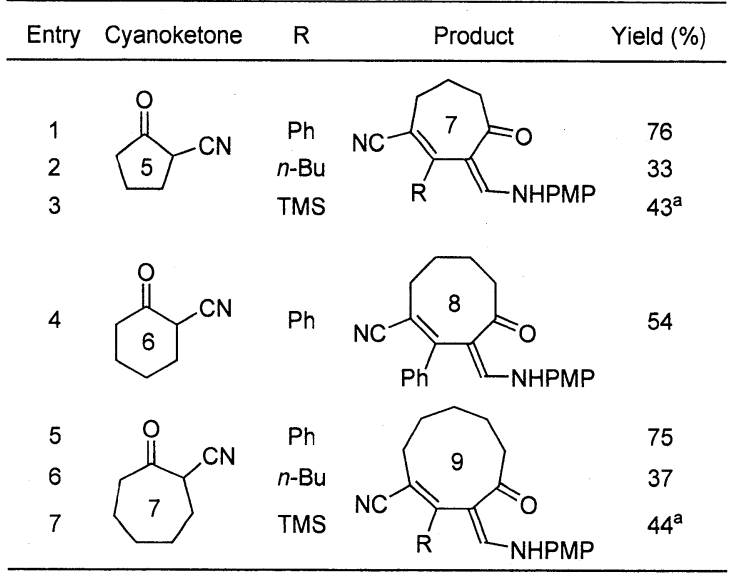

${ }^{\text {a }}$ Desilylated ring expansion products $(R=H)$ were obtained.

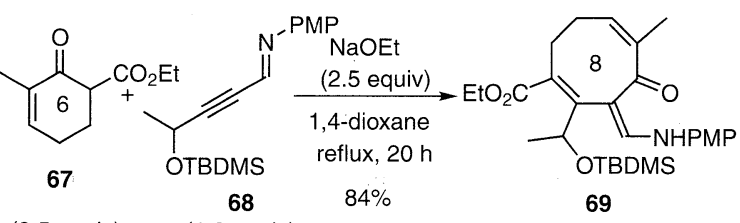

(2.5 equiv) (1.0 equiv)

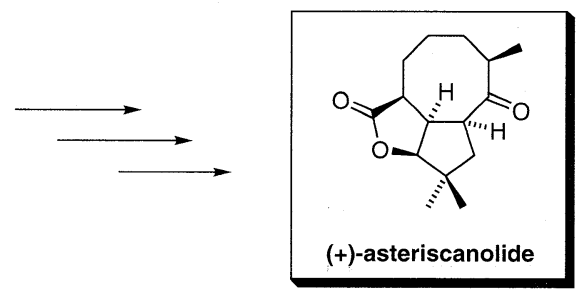

Scheme 14

付加反応によるシクロブテノキシド生成，開環を経る興 味深い反応機構により，多官能基を有する2-ピリドン 掠よび中員環を得ることができる。ここで，求電子剂と してアルキニルイミンのかわりにアルキニルケトン 70 を用いると，2-ピリドン生成反応と同様に進行すれば， 多官能基を有する 2 -ピロン 71 を合成することができる (スキーム 15) $)^{18)}$ 。

tert-ブチルフェニルエチニルケトンに，ジエチルメ チルマロナートのナトリウム塩を，1,4-ジオキサン中加 熱還流下作用させると 5 位にエトキシカルボニル基を有 する2-ピロンを得ることができた(表 8 ，エントリー 1)。この反応では, 置換基によって生成物の収率が異な り，メチルケトンでは2-ピロンは全く得られず，ジエ チルメチルマロナートのナトリウム塩が 1, 4-付加した のみのアルケニルケトン 74 が得られる。また，エチル ケトンでは対応する 2-ピロンは $19 \%$ と低収率であり， 


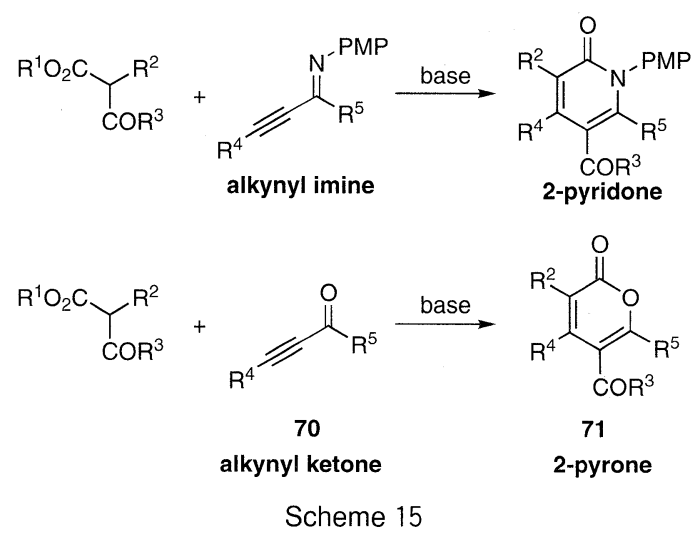

一方，イソプロピルおよびフェニルケトンではそれぞれ 49\%，56\%で対応する 2-ピロン 72 を得ることができ る。アルキニルケトンの置換基として，シクロへキセニ ル基を有するアルキニルケトンでは高収率で対応する 2-ピロン 72 を得ることができる（表 8，エントリー7）。

Table 8 2-Pyrone synthesis via nucleophilic addition of diethyl methylmalonate to alkynyl ketones.
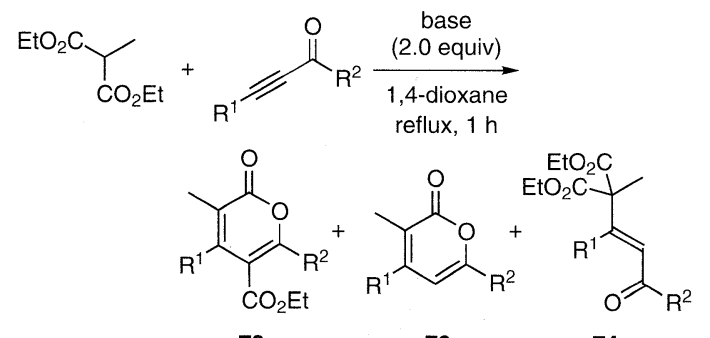

72

73

74

\begin{tabular}{cccccccc}
\hline & & & & \multicolumn{4}{c}{ Yield (\%) } \\
\cline { 5 - 7 } Entry & $\mathrm{R}^{1}$ & $\mathrm{R}^{2}$ & Base & & $\mathbf{7 2}$ & $\mathbf{7 3}$ & $\mathbf{7 4}$ \\
\hline 1 & $\mathrm{Ph}$ & $t-\mathrm{Bu}$ & $\mathrm{NaH}$ & 75 & 9 & \\
2 & $\mathrm{Ph}$ & $t-\mathrm{Bu}$ & $\mathrm{NaOEt}$ & & 80 & 7 & \\
3 & $\mathrm{Ph}$ & $\mathrm{Me}$ & $\mathrm{NaOEt}$ & & & 58 \\
4 & $\mathrm{Ph}$ & $\mathrm{Et}$ & $\mathrm{NaOEt}$ & 19 & 10 & 25 \\
5 & $\mathrm{Ph}$ & $i-\mathrm{Pr}$ & $\mathrm{NaOEt}$ & 49 & 13 & 17 \\
6 & $\mathrm{Ph}$ & $\mathrm{Ph}$ & $\mathrm{NaOEt}$ & 56 & 8 & \\
7 & 1 -cyclohexenyl & $t-\mathrm{Bu}$ & $\mathrm{NaH}$ & 87 & & \\
8 & TBSO $_{\left(\mathrm{CH}_{2}\right)_{3}}$ & $t-\mathrm{Bu}$ & $\mathrm{NaH}$ & 20 & 43 & \\
9 & TBDPSO $\left(\mathrm{CH}_{2}\right)_{3}$ & $t-\mathrm{Bu}$ & $\mathrm{NaH}$ & 24 & 50 & \\
\hline
\end{tabular}

活性メチン化合物として $\beta$-ケトエステルも用いるこ

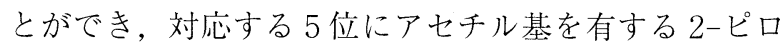
ンを得ることができる(スキーム 16)。

2-ピロン合成の反応機構をスキーム 17 に示す。活性

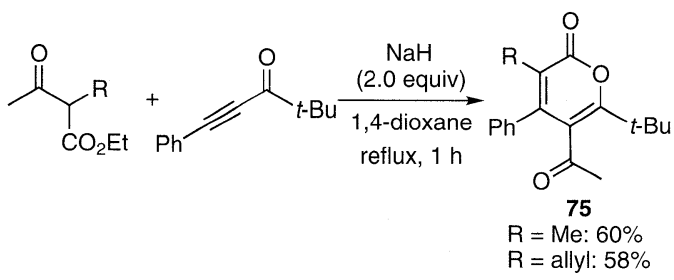

Scheme 16
メチン化合物のナトリウム塩 76 がアルキニルケトン 77 へ共役付加することによって生成したメタロアレノエー ト78 が，分子内求核付加することによってシクロブテ ノキシド 79 が生成し，その後シクロブテノキシド 79 の 開環により，メタルエノラート 80 が生成した後，閉環 することによって，多置換 2-ピロン 81 が生成すると考 えられる(スキーム 17, 経路 a)。

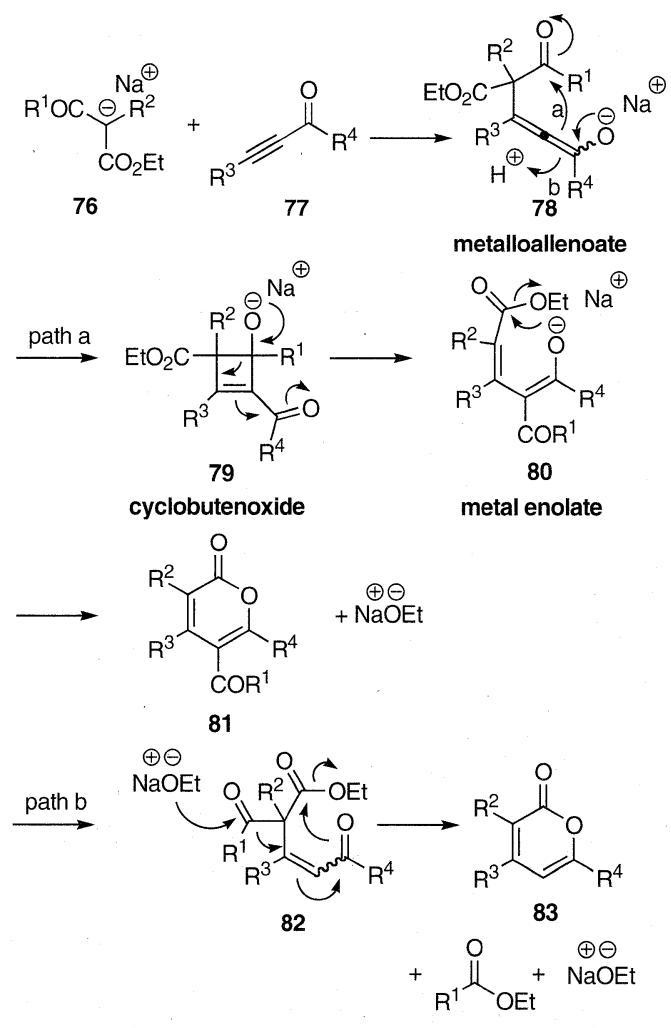

Scheme 17

一方，TBS オキシプロピル基や TBDPS オキシプロ ピル基を有するアルキニルケトンを用いると，5位にエ トキシカルボニル基を持たない 2-ピロンが主生成物と して得られる。これはスキーム17に示したジエチルメ チルマロナートのナトリウム塩 76 が，1,4-付加するこ とによって生成したメタロアレノート 78 のプロトン化 によりアルケニルケトン 82 が生じ, その後, そのアル ケニルケトン $82\left(\mathrm{R}^{1}=\mathrm{OEt}\right)$ のエトキシカルボニル基に ナトリウムエトキシドが求核攻撃し，炭酸ジエチルの脱 離を伴い環化することによって，生成したものと考えら れる(スキーム 17, 経路 b)。そこで次に，この 5 位に エトキシカルボニル基を持たない，すなわち $3,4,6$-三 置換-2-ピロンを得るために，2 位に置換基を有する2メチルメルドラム酸 84 を求核剤に用い，まず 3,4, 5, 6四置換-2-ピロン合成と同様に,アルキニルケトン 85 の 置換基について検討した。その結果, $\mathrm{R}^{2}$ としてイソプ ロピル基，tert-ブチル基およびフェニル基の場合に， 良好な収率で対応する 3,4,6-三置換-2-ピロン 86 を得 ることができた。TBDPS オキシプロピル基を有するア 
Table 9 2-Pyrone synthesis via nucleophilic addition of 2-methyl Meldrum's acid to alkynyl ketones.<smiles>CC1C(=O)OC(C)(C)OC1=O</smiles>

84

(2.5 equiv)

\begin{tabular}{cccc}
\hline Entry & $\mathrm{R}^{1}$ & $\mathrm{R}^{2}$ & Yield (\%) \\
\hline 1 & $\mathrm{Ph}$ & $t-\mathrm{Bu}$ & 79 \\
2 & $\mathrm{Ph}$ & $\mathrm{Me}$ & 0 \\
3 & $\mathrm{Ph}$ & $\mathrm{Et}$ & 11 \\
4 & $\mathrm{Ph}$ & $i-\mathrm{Pr}$ & 60 \\
5 & $\mathrm{Ph}$ & $\mathrm{Ph}$ & 64 \\
6 & $\mathrm{TBDPSO}\left(\mathrm{CH}_{2}\right)_{3}$ & $t-\mathrm{Bu}$ & 71 \\
\hline
\end{tabular}

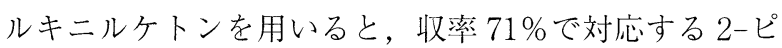
ロンを得ることができる(表 9) ${ }^{19)}$ 。

天然有機化合物には 6 位にアルケニル基を有する $2-$ ピロンが存在することから，その簡便な合成法の開発が

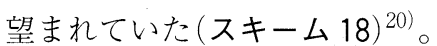<smiles>COc1cc(=O)oc(/C=C/C=C/C=C/C2O[C@@H]3OC(C[N+](=O)[O-])C(O)(O)C3(O)C2O)c1[N+](=O)[O-]</smiles><smiles>COC(=O)COC(=O)/C=C/C=C/C=C/c1oc(=O)cc(OC)c1[N+](=O)[O-]</smiles><smiles>C/C=C(C)/C=C/c1cc(OC)c(OC)c(=O)o1</smiles>

Scheme 18

そこで，6-アルケニル-2-ピロンへ誘導可能な 6-アル キニル-2-ピロン 88 の合成を検討することにした。ま ず，対称なジアルキニルケトン 87 について検討した結 果，フェニル基やブチル基の場合に中程度の収率で， 6 位にアルキニル基を有する2-ピロンを得ることができ た。一方，置換基としてフェニル基と TBSまたは TIPS 基を有する非対称なジアルキニルケトン 87 を用 いると，フェニル基を有する sp 炭素で反応が選択的に 進行した6-アルキニル-2-ピロン 88 を中程度の収率で 得ることができる(表 10)。

反応機構はスキーム 19 に示すように，脱炭酸および 脱アセトンを伴いながら進行していると考えられる。

2-ピロン合成において置換基によって生成物の収率に
Table 10 2-Pyrone synthesis via nucleophilic addition of 2-methyl Meldrum's acid to dialkynyl ketones.

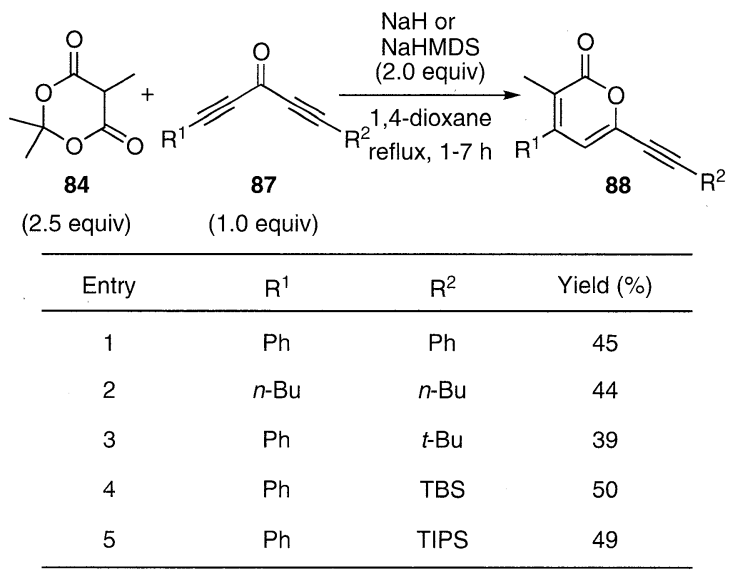

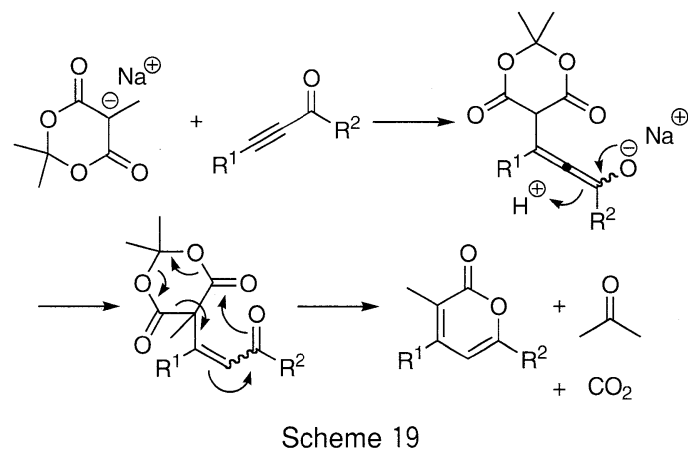

差があることがわかった。特にアルキル基の場合，メチ ル基では全く2-ピロンを得ることができなかった。そ こで，6-メチル-2-ピロンを得るために種々反応条件を 検討した結果，ジメチルメチルマロナートの 1, 4-付加 によって得られるアルケニルケトン 89 を脱メトキシカ ルボニル化の反応条件, すなわちジメチルスルホキシ ド 水混合溶媒中加熱鮞流下，塩化リチウム，塩化ナト

リウムまたは塩化カリウムを作用させたところ，6-メチ ル-2-ピロン 90 が中程度の収率で得られることがわかっ た(表 11)。

Table 11 6-Methyl-2-pyrone synthesis 90 via demethoxycarbonylation of alkenyl ketone 89.

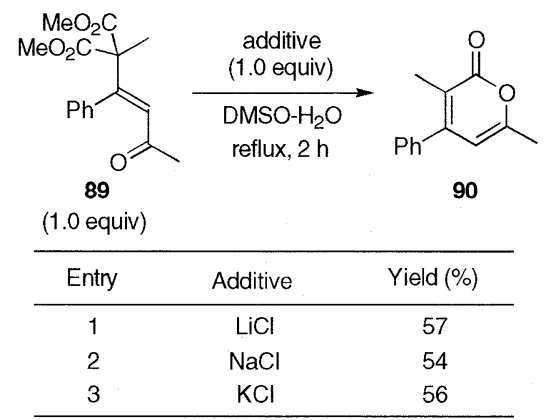

反応機構はスキーム 20 に示してあるように，塩化物 イオンがアルケニルケトンのメトキシカルボニル基のメ チル基への求核攻撃を経て進行していると考えられる。 


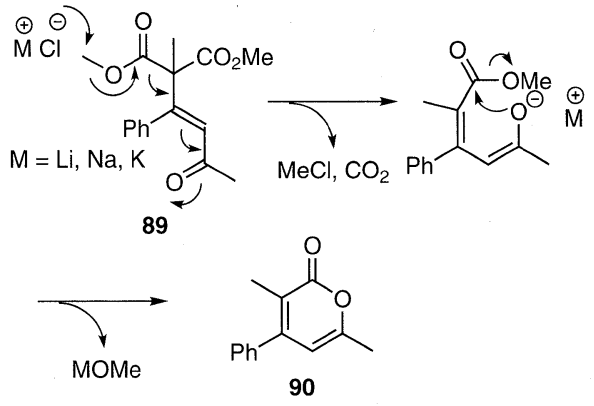

Scheme 20

\section{おわりに}

これまでにも数多くの 2-ピリドン合成反応が報告さ れているが，3 位，4位，5位，および 6 位の置換基を 同時に導入した方法は少ない。本研究で用いたアルキニ ルイミンは，市販の末端アルキンから簡便な操作によっ て合成できる。一方，活性メチン化合物は対応する活性 メチレン化合物のアルキル化または，アリール酢酸エス テルの 2 位のアルコキシカルボニル化によって容易に合 成でき，その結果，様々な置換様式の 2-ピリドンを合 成することができる。本研究を見出すきっかけとなった 反応は，マロン酸ジエステルの 2 位に置換基であるメチ ル基を導入することにより，異性化反応の経路がなくな り，選択的分子内求核付加反応によるシクロブテノキシ ドの生成，開環に引き続く閉環反応が進行することに

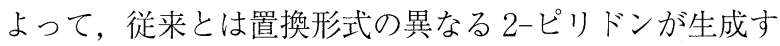
るものである。はじめに想定していた 1,4-1,2-二重求核付 加反応は進行しなかったが，置換基を導入することによ り, 本来異性化反応より進行しにくい分子内求核付加反 応が選択的に進行し，全く新しい反応機構による2-ピリ ドン合成反応の発見を機に，ビシクロ-2-ピリドン合成， 環拡大反応による中員環合成，さらに多置換 2-ピロン合 成を見出すことができた。今後，このように置換基を導 入することにより，本来は選択的に進行しにくい反応を 進行させることにより，従来知られている反応経路とは 異なる反応が進行し，多様な置換形式を有するへテロ環 化合物を合成することが可能になるものと期待される。

最後に, これらの成果は私どもの研究室の学生諸氏の 努力の賜であり，ここに感謝いたします。また，本研究 は文部科学省科学研究費補助金の援助によって行われた ものであり，深謝いたします。

(2005 年 11 月 1 日受理)

\section{文 献}

1) M. Shimizu, A. Morita, T. Kaga, Tetrahedron Lett., 40, 8401 (1999)

2) I. Hachiya, K. Ogura, M. Shimizu, Org. Lett., 4, 2755 (2002)

3) (a) A. Z. Schultz, Chem. Rev., 73, 385 (1973); (b) D. P. Curran, H. Liu, J. Am. Chem. Soc., 114, 5863 (1992); (c) A. P. Kozikowski, G. Campiani, L.-Q. Sun, ibid., 118, 11357 (1996); (d) D. R. Williams, P. D. Lowder, Y.-G. Gu, Tetrahedron Lett. 38, 327 (1997); (e) M.-L. Bennasar, E. Zulaica, C. Juan, Y. Alonso, J. Bosch, J. Org. Chem., 67, 7465 (2002); (f) P. Fossa, G. Menozzi, P. Dorigo, M. Floreani, L. Mosti, Bioorg. Med. Chem., 11, 4749 (2003)

4）総説: (a) D. M. Smith, "Comprehensive Organic Chemistry" ed. by D. H. R. Barton, W. D. Ollis, Pergamon Press, Oxford, 1979, Vol. 4, p 3; (b) A. McKillop, A. J. Boulton, "Comprehensive Heterocyclic Chemistry" ed. by A. R. Katritzky, C. W. Rees, Pergamon Press, New York, 1984, Part 2 A, Vol. 2, p 67; (c) G. Jones, "Comprehensive Heterocyclic Chemistry" ed. by A. R. Katritzky, C. W. Rees, Pergamon Press, New York, 1984, Part 2 A, Vol. 2, p 395

5) (a) Y. Yamamoto, H. Takagishi, K. Itoh, Org. Lett., 3, 2117 (2001); (b) T. Takahashi, F.-Y. Tsai, Y. Li, H. Wang, Y. Kondo, M. Yamanaka, K. Nakajima, M. Kotora, J. Am. Chem. Soc., 124, 5059 (2002)

6) K. Afarinkia, V. Vinader, T. D. Nelson, G. H. Posner, Tetrahedron, 48, 9111 (1992)

7) I. Hachiya, K. Ogura, M. Shimizu, Synthesis, 2004, 1349

8）投稿中, I. Hachiya, S. Fukushima, M. Shimizu, 3,4,5,6-Tetrasubstituted-2-pyridone Synthesis via Nucleophilic Addition of Active Methine Compounds to Dialkynyl Imines Directed to the Synthesis of (-)-A 58365 A

9) A. V. Kel'in, A. W. Sromek, V. Gevorgyan, J. Am. Chem. Soc., 123, 2074 (2001)

10) (a) D. Mihelic, R. Jakse, J. Svete, B. Stanovnik, S. Golic-Grdadolnik, J. Heterocycl. Chem., 38, 1307 (2001); (b) T. Nicola, D. Schwarzrock, M. Keller, W. Eberbach, Tetrahedron, 57, 1771 (2001); (c) F. Al-Omran, A.-Z. A. Elassar, A. A. El-Khair, ibid., 57, 10163 (2001); (d) D. Mihelic, R. Jakse, J. Svete, B. Stanovnik, S. Golic-Grdadolnik, J. Heterocycl. Chem., 38, 1307 (2001); (e) F. Bihel, R. Faure, J.-L. Kraus, Org. Biomol. Chem., 1, 800 (2003); (f) J. Westman, R. Lundin, Synthesis, 2003, 1025; (g) Y. M. Volovenko, T. V. Shokol, Chemistry of Heterocyclic Compounds, 39, 545 (2003)

11) I. Hachiya, M. Atarashi, M. Shimizu, Heterocycles, 67, 523 (2006)

12) (a) K. T. Potts, K. C. Hsia, J. Org. Chem., 38, 3485 (1973); (b) A. Copar, B. Stanovnik, M. Tisler, Bull. Soc. Chim. Belg., 100, $533(1991)$

13) (a) R. A. Coburn, R. A. Glennon, J. Heterocycl. Chem., 10, 487 (1973); (b) K. T. Potts, S. Kanemasa, J. Org. Chem., 44, 3808 (1979)

14) A. H. Hunt, J. S. Mynderse, S. K. Samlaska, D. S. Fukuda, G. M. Maciak, H. A. Kirst, J. L. Occolowitz, J. K. Swartzendruber, N. D. Jones, J. Antibiot., 41, 771 (1988), and references cited therein

15) (a) F. G. Fang, S. Danishefsky, Tetrahedron Lett., 30, 3621 (1989); (b) A. Padwa, S. M. Sheehan, C. S. Straub, J. Org. Chem., 64, 8648 (1999); (c) A. Reichelt, S. K. Bur, S. F. Mar tin, Tetrahedron, 58, 6323 (2002) and references cited therein

16）投稿中, I. Hachiya, W. Maehara, Y. Yamada, T. Kamiki, M. Shimizu, Ring Expansion Reaction via Nucleophilic Addition of Cyclic $\beta$-Ketoesters to Alkynyl Imines

17) (a) P. A. Wender, N. C. Ihel, C. R. D. Correia, J. Am. Chem. Soc., 110, 5904 (1988); (b) L. A. Paquette, J. Tae, M. P. Arrington, A. H. Sadoun, ibid., 122, 2742 (2000)

18) I. Hachiya, H. Shibuya, M. Shimizu, Tetrahedron Lett., 44, 2061 (2003)

19) I. Hachiya, H. Shibuya, K. Hanai, M. Shimizu, Lett. Org. Chem., 1, 349 (2004)

20) (a) S. L. Schreiber, K. Satake, J. Am. Chem. Soc., 106, 4186 (1984); (b) H. Venkataraman, J. K. Cha, Tetrahedron Lett., 28, 2455 (1987); (c) R. R. Vardaro, V. D. Marzo, A. Crispino, G. Cimino, Tetrahedron, 47, 5569 (1991) 


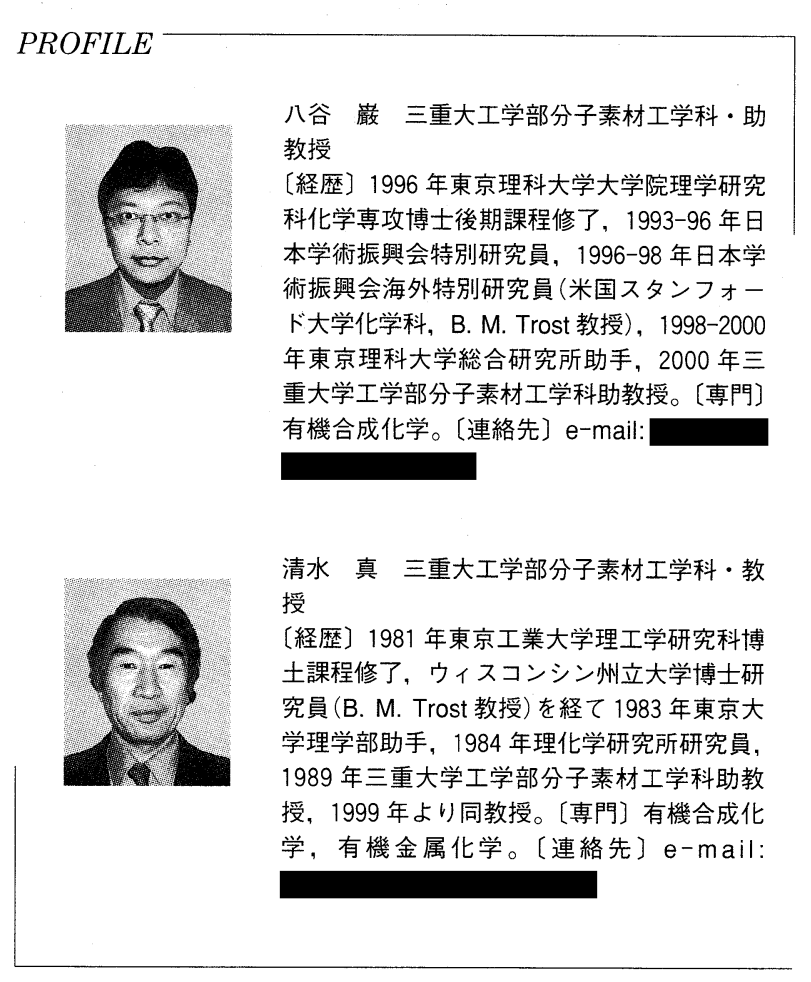

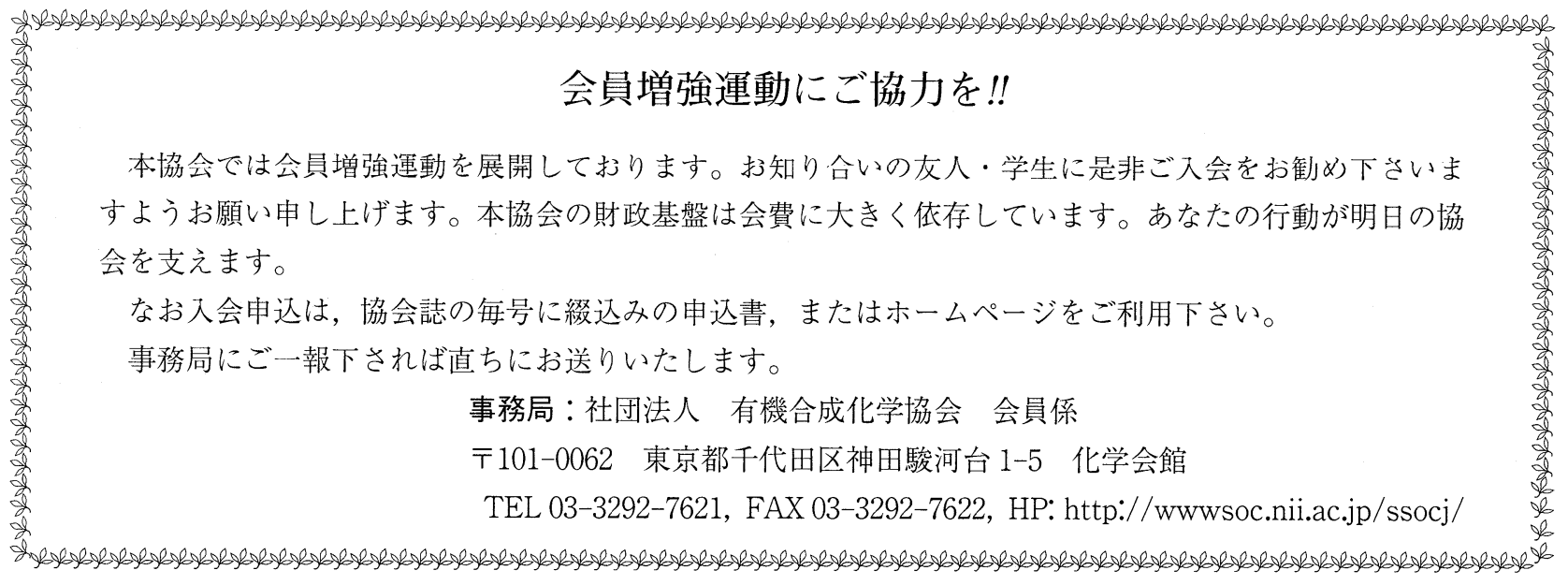

